J. Dairy Sci. 98:5621-5629

http://dx.doi.org/10.3168/jds.2015-9367

(C) American Dairy Science Association ${ }^{\circledR}, 2015$.

\title{
Effects of solid feed level and roughage-to-concentrate ratio on ruminal drinking and passage kinetics of milk replacer, concentrates, and roughage in veal calves
}

\author{
H. Berends, ${ }^{11,2}$ J. J. G. C. van den Borne, ${ }^{*}$ N. Stockhofe-Zurwieden, $†$ M. S. Gilbert, ${ }^{*}$ T. Zandstra, ${ }^{*}$ \\ W. F. Pellikaan, ${ }^{*}$ C. G. van Reenen, $\ddagger$ E. A. M. Bokkers,§ and W. J. J. Gerrits* \\ ${ }^{*}$ Animal Nutrition Group, Wageningen University, PO Box 338, 6700 AH Wageningen, the Netherlands \\ †Central Veterinary Institute, Wageningen University and Research Centre, PO Box 65, 8200 AB Lelystad, the Netherlands \\ fLivestock Research, Animal Sciences Group, Wageningen University and Research Centre, PO Box 65, 8200 AB Lelystad, the Netherlands \\ $\S$ Animal Production Systems Group, Wageningen University, PO Box 338, 6700 AH Wageningen, the Netherlands
}

\section{ABSTRACT}

Effects of solid feed (SF) level and roughage-to-concentrate $(\mathrm{R}: \mathrm{C})$ ratio on ruminal drinking and passage kinetics of milk replacer, concentrate, and roughage were studied in veal calves. In total, 80 male HolsteinFriesian calves ( $45 \pm 0.2 \mathrm{~kg}$ of body weight) were divided over 16 pens ( 5 calves per pen). Pens were randomly assigned to either a low (LSF) or a high (HSF) SF level and to 1 of 2 R:C ratios: 20:80 or 50:50 on a dry matter (DM) basis. Roughage was composed of $50 \%$ corn silage and $50 \%$ chopped wheat straw on a DM basis. At 27 wk of age, measurements were conducted in 32 calves. During the measurement period, SF intake was $1.2 \mathrm{~kg}$ of DM/d for LSF and $3.0 \mathrm{~kg}$ of DM/d for HSF, and milk replacer intake averaged $2.3 \mathrm{~kg}$ of $\mathrm{DM} / \mathrm{d}$ for LSF and $1.3 \mathrm{~kg}$ of DM/d for HSF. To estimate passage kinetics of milk replacer, concentrate, and straw, indigestible markers (CoEDTA, hexatriacontane $\mathrm{C}_{36}$, Cr-neutral detergent fiber) were supplied with the feed as a single dose 4,24 , and $48 \mathrm{~h}$ before assessment of their quantitative recovery in the rumen, abomasum, small intestine, and large intestine. Rumen Co recovery averaged $20 \%$ of the last milk replacer meal. Recoveries of Co remained largely unaffected by SF level and R:C ratio. The $\mathrm{R}: \mathrm{C}$ ratio did not affect rumen recovery of $\mathrm{C}_{36}$ or Cr. Rumen fractional passage rate of concentrate was estimated from recovery of $\mathrm{C}_{36}$ in the rumen and increased from $3.3 \% / \mathrm{h}$ for LSF to $4.9 \% / \mathrm{h}$ for HSF. Rumen fractional passage rate of straw was estimated from $\mathrm{Cr}$ recovery in the rumen and increased from $1.3 \% / \mathrm{h}$ for LSF to $1.7 \% / \mathrm{h}$ for HSF. An increase in SF level was accompanied by an increase in fresh and dry rumen

\footnotetext{
Received January 21, 2015.

Accepted May 1, 2015.

${ }^{1}$ Corresponding author: Harma.Berends@nutreco.com

${ }^{2}$ Current address: Trouw Nutrition R\&D, Veerstraat 38, $5831 \mathrm{JN}$ Boxmeer, the Netherlands.
}

contents. In HSF calves, pH decreased and VFA concentrations increased with increasing concentrate proportion, indicating increased fermentation. The ratio between $\mathrm{Cr}$ and $\mathrm{C}_{36}$ was similar in the small and large intestine, indicating that passage of concentrate and straw is mainly determined by rumen and abomasum emptying. In conclusion, increasing SF level introduces large variation in passage kinetics of dietary components, predominantly in the rumen compartment. The $\mathrm{SF}$ level, rather than the R:C ratio, influences rumen recovery of concentrate and roughage. Our data provide insight in passage kinetics of milk (Co representing the milk replacer) and $\mathrm{SF}$ (Cr and $\mathrm{C}_{36}$ representing roughage and concentrate, respectively) and may contribute to the development of feed evaluation models for calves fed milk and SF.

Key words: calves, passage rate, nutrient utilization, forage-to-concentrate ratio

\section{INTRODUCTION}

Provision of a minimum amount (50 to $250 \mathrm{~g} / \mathrm{d}$ ) of fibrous feed for veal calves is compulsory according to guidelines of the European Union (97/2/EC Directive by the EU Council). Solid feed (SF) provision reduces abnormal oral behaviors (Kooijman et al., 1991; Veissier et al., 1998; Webb et al., 2012), and therefore contributes to improved calf welfare. Furthermore, an economic incentive exists to replace MR by $\mathrm{SF}$ in veal calf diets due to increasing prices of milk replacer (MR) ingredients. With increasing amounts of SF provided, products from rumen fermentation contribute to maintenance requirements and growth at the expense of nutrients from MR. In a previous study, we showed that the contribution of $\mathrm{SF}$ and $\mathrm{MR}$ to $\mathrm{BW}$ gain of veal calves largely follows its contribution to digestible energy supply, but effects of age exist (Berends et al., 2012a, 2014). Underlying mechanisms are not 
clear, but it is likely that variation in rumen passage kinetics of SF components and ruminal drinking largely contributes to variation in digestible energy supply. No information exists on passage kinetics of dietary components throughout the gastrointestinal tract in veal calves fed a combination of MR and SF. In dairy calves, it was shown that reducing MR intake (up to 60\% compared with a control) had only minor effects on rumen passage kinetics of SF (Broesder et al., 1990). In addition, roughage-to-concentrate $(\mathbf{R}: \mathbf{C})$ ratio (Colucci et al., 1982; Poore et al., 1990; Rotger et al., 2005), as well as SF level (Colucci et al., 1990), may affect passage kinetics, as observed in ruminants fed only SF. In calves, MR is generally assumed to bypass the reticulorumen by means of the esophageal groove reflex. However, MR may leak into the rumen due to a failure of the esophageal groove reflex or backflow of MR from the abomasum, referred to as ruminal drinking, which can be substantial in dairy calves (0-25\%; Guilhermet et al., 1975; Abe et al., 1979) and veal calves (14 to 35\%; Suárez et al., 2007; Berends et al., 2012b). The objective of the current study was to assess the effects of SF level and R:C ratio on ruminal drinking and passage kinetics of dietary components in veal calves fed $\mathrm{MR}$, roughage, and concentrate.

\section{MATERIALS AND METHODS}

This study was conducted at the research facilities of VanDrie group (Scherpenzeel, the Netherlands). Procedures complied with the Dutch Law on Experimental Animals and the ETS123 (Council of Europe 1985 and the $86 / 609 /$ EEC Directive) and were approved by the Animal Care and Use Committee of Wageningen University.

\section{Animals, Experimental Design, and Housing}

Eighty male Holstein-Friesian calves (2 wk of age; 45 $\pm 0.2 \mathrm{~kg}$ of BW) were purchased from commercial dairy farms and selected based on uniformity and clinical health. Calves were allocated to pens ( 5 calves per pen; 16 pens) based on BW. Pens were randomly assigned to 1 of 2 SF levels - a low SF level (LSF) or a high SF level (HSF) - and to an R:C ratio of either 20:80 or 50:50 (Table 1). Upon arrival, calves were adapted to the designated SF levels at a fixed R:C of 50:50 until wk 10. During the experimental period (wk 11 to 27 after arrival), calves were exposed to their assigned SF level and R:C ratio. During the last $2 \mathrm{~d}$ of the experimental period, passage kinetics were measured in 32 calves originating from 16 pens.

During the experimental period, calves were housed in groups of 5 calves in pens $(3 \times 3 \mathrm{~m})$ equipped with wooden-slatted floors and fences and without bedding material. During the last $2 \mathrm{~d}$ of the experimental period, 2 calves per pen were randomly selected and housed in individual pens placed inside the group pen to facilitate individual feeding and monitoring. Individual pens measured $0.9 \times 2.0 \mathrm{~m}$ and allowed audio-visual contact with group mates. Throughout the experiment, calves were exposed to daylight and artificial light from 0500 to $2300 \mathrm{~h}$ and to darkness during the remainder of the day. Animal health was checked daily by visual appraisal. Hemoglobin concentration in blood was measured across the trial at wk 11, 15, 19, and 23 and corrected by iron injection to comply with the minimum European Union level of $4.5 \mathrm{mmol} / \mathrm{L}$ at the end of the fattening period.

\section{Diets and Feeding}

The calves in the current study were selected from another experiment, which has been described by Berends et al. (2014). In short, roughage was composed of $50 \%$ corn silage (Table 2) and $50 \%$ chopped ( $3 \pm 2$ $\mathrm{cm}$ ) wheat straw (Table 2) on a DM basis. Provision of SF increased biweekly and linearly during the experimental period (wk 11-27), and averaged $780 \mathrm{~g}$ of $\mathrm{DM} / \mathrm{d}$ for LSF and 2,000 $\mathrm{g}$ of $\mathrm{DM} / \mathrm{d}$ for HSF.

Daily DMI from MR during the measurement period is shown in Table 1 . The concentration of MR (Table 3) was $188 \mathrm{~g} / \mathrm{L}$ throughout the experimental period. The MR was supplied in buckets at 40 to $41^{\circ} \mathrm{C}$, provided twice daily in equally sized meals at 0600 and $1600 \mathrm{~h}$, respectively. Calves were allowed $15 \mathrm{~min}$ to consume the milk; refusals were collected.

The SF was prepared in a mixing wagon (Easymix 2, Vliebo, Veenendaal, the Netherlands), and provided as a mixture in a long feed trough in front of the pen directly after MR provision and collection of MR refusals. Solid feed refusals were removed and weighed once daily before the MR meal in the morning. During the experimental period, calves had free access to water provided via drinking nipples. During the 2 -d measure-

Table 1. Daily DM provision of solid feed (SF) and milk replacer ( $\mathrm{g}$ of $\mathrm{DM} /$ calf per day) in calves $(\mathrm{n}=8$ per treatment combination) fed at 1 of 2 levels of SF intake, at 1 of 2 roughage-to-concentrate ratios $(\mathrm{R}: \mathrm{C})^{1}$ at $27 \mathrm{wk}$ of age

\begin{tabular}{|c|c|c|c|c|}
\hline \multirow[b]{2}{*}{ Type of feed } & \multicolumn{2}{|c|}{ Low SF } & \multicolumn{2}{|c|}{ High SF } \\
\hline & $20: 80$ & $50: 50$ & $20: 80$ & $50: 50$ \\
\hline Solid feed & \multicolumn{2}{|c|}{1,170} & \multicolumn{2}{|c|}{3,000} \\
\hline Milk replacer & 2,224 & 2,370 & 1,058 & 1,458 \\
\hline
\end{tabular}

${ }^{1}$ Roughage consisted of $50 \%$ corn silage and $50 \%$ chopped wheat straw on a DM basis. 
ment period (wk 27), calves were provided with water in buckets for $15 \mathrm{~min}$ at 1200 and $2200 \mathrm{~h}$.

\section{Measurements}

Feed Intake and Performance. Milk replacer intake and SF intake were measured daily. Calves were weighed every 2 wk.

Markers. Indigestible markers were used to estimate kinetics of MR, concentrate (hexatriacontane), and straw along the digestive tract of calves Passage kinetics were assessed by measuring the recovery of external markers from 4 compartments of the gastrointestinal tract at slaughter; reticulorumen, abomasum, small intestine, and large intestine. Each marker was provided as a pulse dose and in a proportionate mixture with the other SF components corresponding to the treatment. To assess passage kinetics of roughage, chromiummordanted fiber straw with similar particle size of $3 \pm$ $2 \mathrm{~cm}$ (Cr-NDF; $50 \mathrm{~g} /$ calf) was provided with the SF $48 \mathrm{~h}$ before slaughter. In total, most $(\mathrm{n}=27)$ calves consumed the pulse dose with Cr-NDF within $120 \mathrm{~min}$. The Cr-NDF was prepared as described by Udén et al. (1980) with the same straw as included in the SF. To assess ruminal drinking and passage kinetics of MR, 36 $\mathrm{g}$ of cobalt(II)EDTA (CoEDTA; Udén et al., 1980) was dissolved into the final MR meal and provided to each calf at $4 \mathrm{~h}$ before slaughter. Calves were allowed 15 min to consume the meal. To assess passage kinetics of concentrate particles, $6 \%$ of hexatriacontane $\left(\mathbf{C}_{36}\right.$; $>95.0 \%$ wt/wt, Minakem, Beuvry-la-Forêt, France) was included in the concentrate (Table 2). The enriched concentrate was provided with the SF $24 \mathrm{~h}$ before slaughter. In total, $88 \%$ of calves consumed the pulse dose with $\mathrm{C}_{36}$ within 60 min.

Slaughter Procedure. At the end of the measurement period, calves were slaughtered at the experimental facilities over 2 consecutive slaughter days. Euthanasia by pentobarbital was directly followed by exsanguination. To avoid reflux of MR from the abomasum into the forestomachs at slaughter, calves were lifted by the forelegs immediately following exsanguination. Subsequently, ligations were made at the level of the thoracic entrance, the omasal-cardia of the abomasum, and the reticulo-omasal orifice. The gastrointestinal tract was divided into 4 segments: reticulorumen, abomasum, small intestine, and large intestine. The weight of each segment was recorded with and without contents. $\mathrm{Ru}-$ men contents were quantitatively collected and solid and liquid phases were separated using a metal sieve $(1.5 \mathrm{~mm})$. After weighing the solid and liquid phase, a proportionate sample of rumen contents was prepared by reconstituting samples of the liquid and solid phases,
Table 2. Analyzed nutrient composition (\% of DM, unless otherwise indicated) of concentrate, corn silage, and straw

\begin{tabular}{lccc}
\hline Nutrient & Concentrate $^{1}$ & $\begin{array}{c}\text { Corn } \\
\text { silage }\end{array}$ & $\begin{array}{c}\text { Wheat } \\
\text { straw }\end{array}$ \\
\hline DM, \% of product & 89.8 & 29.7 & 93.1 \\
CP $^{2}$ & 13.7 & 6.9 & 3.1 \\
Crude fat & 6.7 & 2.9 & 0.9 \\
Starch & 42.9 & 31.2 & 1.1 \\
NDF & 12.7 & 42.1 & 79.4 \\
\hline
\end{tabular}

${ }^{1}$ Concentrate composition: $36.2 \%$ corn, $20.6 \%$ lupins, $20.3 \%$ barley $12.5 \%$ carob meal, $4.4 \%$ corn gluten meal, $6 \%$ premix (lactose carrier). Provided per kilogram of concentrate: vitamin A, 4,000 IU; vitamin D, $500 \mathrm{IU}$; vitamin E, $100 \mathrm{IU}$; zinc $\left(\mathrm{ZnSO}_{4}\right), 25 \mathrm{mg}$; manganese $\left(\mathrm{MnSO}_{4}\right)$, $20 \mathrm{mg}$; iodine (KI), $0.8 \mathrm{mg}$; iron $\left(\mathrm{FeSO}_{4}\right), 63 \mathrm{mg}$; selenium $\left(\mathrm{Na}_{2} \mathrm{SeO}_{3}\right)$, $0.15 \mathrm{mg}$; copper $\left(\mathrm{CuSO}_{4}\right), 15 \mathrm{mg}$; cobalt, $0.1 \mathrm{mg} ; 1.13 \mathrm{~g}$ of magnesium (magnesium sulfate), $3.0 \mathrm{~g}$ of sodium $(\mathrm{NaCl}), 8.6 \mathrm{~g}$ of calcium $\left(\mathrm{CaCO}_{3}\right)$, and $3.9 \mathrm{~g}$ of potassium $\left(\mathrm{KH}_{2} \mathrm{PO}_{4}\right)$.

${ }^{2} \mathrm{~N} \times 6.25$

which was oven-dried and stored for analysis. A sample of the rumen liquid was used for $\mathrm{pH}$ measurement, then acidified with $\mathrm{H}_{3} \mathrm{PO}_{4}(5 \%)$ and stored at $-20^{\circ} \mathrm{C}$ pending analysis of VFA. After mixing, samples of abomasal contents, small intestinal contents, and large intestinal contents were taken and stored at $-20^{\circ} \mathrm{C}$ pending analysis. The length of small intestine was measured.

Table 3. Ingredient composition and analyzed nutrient composition of the experimental milk replacer

\begin{tabular}{lc}
\hline Item & Amount \\
\hline Ingredient, \% $^{1}$ & \\
Fat-filled whey powder $^{1}$ & 39.4 \\
Whey protein concentrate & 19.4 \\
Whey & 14.3 \\
Delactosed whey & 13.5 \\
Soy protein isolate & 3.8 \\
Soy protein concentrate & 2.5 \\
Acidified whey ${ }^{2}$ & 2.0 \\
Pregelatinized wheat starch & 2.0 \\
Vitamin and mineral premix ${ }^{3}$ & 1.0 \\
Calcium formate & 1.0 \\
L-Lysine·HCl & 0.5 \\
DL-Methionine & 0.3 \\
Citric acid & 0.2 \\
Mono-ammonium phosphate & 0.1 \\
L-Threonine & 0.02 \\
Nutrient, \% of DM (unless otherwise stated) & \\
DM, \% of product & 97.0 \\
CP & 21.0 \\
Crude fat & 21.2 \\
Starch & 2.2 \\
\hline
\end{tabular}

${ }^{1}$ Contained $50 \%$ fat, palm oil and coconut oil (80/20, wt/wt).

${ }^{2}$ Acidified with lactate, provided $5.9 \mathrm{~g}$ of lactate $/ \mathrm{kg}$ of the experimental diet.

${ }^{3}$ Provided per kilogram of the experimental diet: $16.6 \mathrm{~g}$ of $\mathrm{K}, 15.5 \mathrm{~g}$ of $\mathrm{Cl}, 8.3 \mathrm{~g}$ of $\mathrm{Fe}, 6.1 \mathrm{~g}$ of $\mathrm{P}, 5.9 \mathrm{~g}$ of $\mathrm{Cu}\left(\mathrm{CuSO}_{4}\right), 5.7 \mathrm{~g}$ of $\mathrm{Na}, 1.3 \mathrm{~g}$ of $\mathrm{Mg}(\mathrm{MgO}), 25,000 \mathrm{IU}$ of vitamin $\mathrm{A}, 4,000 \mathrm{IU}$ of vitamin $\mathrm{D}_{3}$, and 100 IU of vitamin E.

${ }^{4}$ Calculated as $\mathrm{N} \times 6.25$. 
Chemical Analyses. Samples of MR, concentrate, corn silage, and wheat straw were collected weekly. Corn silage samples were pooled monthly; other samples were pooled over the experimental period. Feed components (MR, corn silage, concentrate, straw) were analyzed for DM, ash, N, starch, NDF (except for MR), and crude fat content. For determination of DM content, corn silage and concentrate samples were freezedried. Concentrate, straw, and corn silage samples were ground to pass a 1-mm screen. Dry matter content was determined by drying to a constant weight according to ISO 6496 (ISO, 1998). Kjeldahl N content was determined according to ISO 5983 (ISO, 1997). Starch content was determined enzymatically as described by Rijnen et al. (2001). The NDF content was analyzed according to Van Soest et al. (1991). Crude fat content was determined after acid hydrolysis according to ISO 6496 (ISO, 1999). Concentrations of VFA in rumen liquid were quantified by GC (Fisons HRGC Mega 2, CE Instruments, Milan, Italy) according to Pellikaan et al. (2011).

The $\mathrm{Cr}$ and $\mathrm{Co}$ concentrations were determined in the contents from each gastrointestinal compartment by atomic absorption spectrometry according to Pellikaan et al. (2013). Extraction and analysis of $n$-alkanes was carried out according to Bezabih et al. (2011). Ground samples were pulverized using a ball mill (MM 2000; 4 min at $80 \mathrm{~Hz}$; Retsch Technology GmbH, Haan, Germany) before extraction and analysis, as described by Mayes et al. (1986) with modifications of Salt et al. (1992) using tetratriacontane as an internal standard. The extracted samples were analyzed for $\mathrm{C}_{36}$ using a GC. The concentration of $\mathrm{C}_{36}$ was calculated from peak areas using an internal standard (Bezabih et al., 2011).

Calculations. Rumen fractional passage rates were assumed constant and estimated for concentrate and straw from rumen recoveries of $\mathrm{C}_{36}$ and $\mathrm{Cr}$, respectively, according to the formula:

$$
\mathrm{C}_{\mathrm{t}}=\mathrm{C}_{0} \times \mathrm{e}^{-\mathrm{kp} \times \mathrm{t}}
$$

where $\mathrm{C}_{\mathrm{t}}$ is the marker concentration at time $\mathrm{t}, \mathrm{C}_{0}$ is the marker concentration at time $0, \mathrm{kp}$ is the fractional passage rate, and $\mathrm{t}$ is time in $\mathrm{h}$.

Statistical Analysis. The data set included 32 observations. For Co recovery, 8 calves were excluded because of MR refusals exceeding 10\% (1 LSF 50:50; 5 LSF 20:80; 2 HSF 50:50). Dependent variables were analyzed by mixed model analysis in PROC MIXED (SAS 9.20 by SAS Institute Inc., Cary, NC) for continuous data, with calf as experimental unit, pen as random effect, and SF level, R:C ratio, and day of slaughter as fixed effects, and the interaction between SF level and
$\mathrm{R}: \mathrm{C}$ ratio. Results are presented as least squared means and their standard error of the mean. Differences were considered significant at $P<0.05$.

\section{RESULTS}

During the experimental period (wk 11 to 27), LSF calves consumed $93 \pm 2.9$ and $94 \pm 0.3 \mathrm{~kg}$ of DM of $\mathrm{SF}$ and $251 \pm 6.2$ and $232 \pm 1.4 \mathrm{~kg}$ of DM of MR for R:C 50:50 and 20:80, respectively. In the same period, HSF calves consumed $239 \pm 0.9$ (R:C 50:50) and 248 $\pm 1.6 \mathrm{~kg}$ of DM of SF (R:C 20:80) and $184 \pm 1.7$ and $150 \pm 0.9 \mathrm{~kg}$ of DM of MR, respectively. Final BW was greater $(P<0.05)$ for calves fed HSF $(259 \pm 4.2$ $\mathrm{kg})$ than for calves fed LSF $(245 \pm 5.9 \mathrm{~kg})$, but growth performance was not affected by $\mathrm{R}: \mathrm{C}$ ratio.

Recovery of Co in the rumen averaged $20 \pm 4.0 \%$. Rumen and small and large intestinal Co recovery was unaffected by SF level and R:C ratio (Table 4). Abomasal Co recovery was greater $(P=0.01)$ in LSF calves than in HSF calves. Rumen recovery of $\mathrm{C}_{36}$ was unaffected by R:C ratio, but decreased by $15 \%$ points $(P<$ $0.001)$ with SF level. This difference was reflected in the cumulative $\mathrm{C}_{36}$ recovery. Rumen recovery of $\mathrm{Cr}$ was unaffected by R:C ratio, but decreased by $8 \%$ points $(P$ $=0.002)$ with SF level. This difference was reflected in the cumulative $\mathrm{Cr}$ recovery. Recoveries of $\mathrm{Cr}$ and $\mathrm{C}_{36}$ in abomasum and small intestine were generally low $(<5 \%)$. For the abomasum, recoveries of $\mathrm{Cr}$ and $\mathrm{C}_{36}$ increased with roughage inclusion for the LSF calves, and decreased with roughage inclusion for the $\mathrm{HSF}$ calves. For the small intestine, recoveries of $\mathrm{Cr}$ and $\mathrm{C}_{36}$ decreased with roughage inclusion for the LSF calves, whereas the opposite was true for the HSF calves (SF $\times \mathrm{R}$ :C interaction, $P=0.01)$.

At high SF intake, a low $\mathrm{R}: \mathrm{C}$ ratio resulted in a 1-point lower $\mathrm{pH}(P=0.004$; Table 5$)$ and a higher total VFA concentration $(37 \mathrm{mmol} / \mathrm{L}$; SF $\times \mathrm{RC}, P=$ 0.04). The SF level did not affect empty weights of the gastrointestinal compartments, but rumen contents (fresh as well as dry) increased $(P<0.001)$ in response to an increase in SF level. DM content of digesta in the rumen and abomasum decreased in 20:80 compared with 50:50 (both $P<0.05$ ). The empty weight of the abomasum increased $(P=0.01)$ in 50:50 compared with 20:80. Small intestinal weight, contents, and length were unaffected by $\mathrm{SF}$ level or $\mathrm{R}$ : $\mathrm{C}$ ratio. The empty weight of the large intestine increased in 20:80 compared with 50:50 in HSF calves only (interaction $\mathrm{SF} \times \mathrm{RC}, P=0.05)$.

From rumen recoveries of $\mathrm{Cr}$ and $\mathrm{C}_{36}$, the fractional rates of passage were estimated (Table 6). Ruminal fractional passage rate of $\mathrm{C}_{36}$, representing concentrate, 
Table 4. Effects of level of solid feed (SF; low vs. high) and roughage-to-concentrate ratio (R:C; 20:80 vs. 50:50) on the recovery of pulse-dosed markers, $\mathrm{Co}, \mathrm{Cr}$, and hexatriacontane $\left(\mathrm{C}_{36}\right)$, in gastrointestinal compartments of veal calves ${ }^{1}$

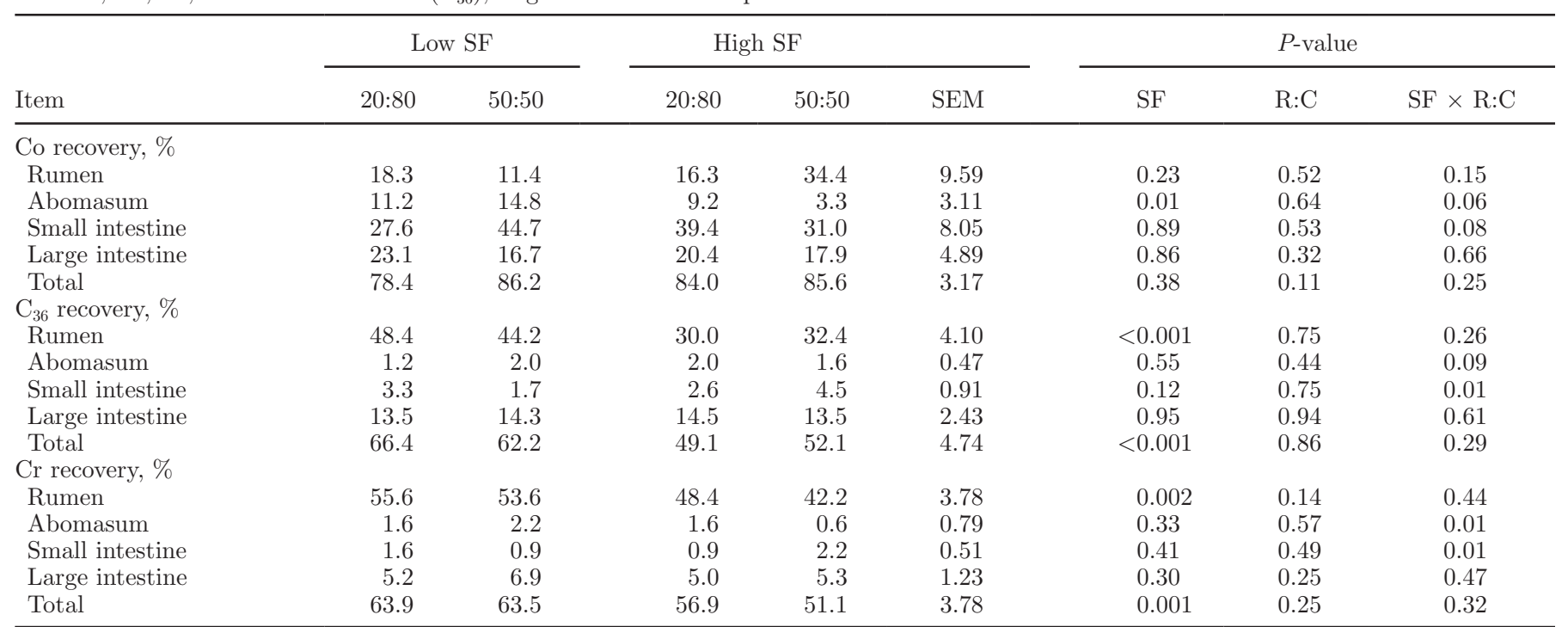

${ }^{1}$ Dietary treatments included low or high level of solid feed (SF). The SF included 1 of 2 roughage-to-concentrate ratios (R:C; 20:80 vs. $50: 50$ on $\mathrm{DM}$ basis) and was fed in addition to a milk replacer. Cobalt was pulse-dosed as CoEDTA with milk replacer at $4 \mathrm{~h}$ before slaughter; $\mathrm{C}_{36}$ was pulse-dosed with concentrate in SF at $24 \mathrm{~h}$ before slaughter; $\mathrm{Cr}$ was pulse-dosed as Cr-NDF with wheat straw in SF at $48 \mathrm{~h}$ before slaughter.

increased $(P<0.001)$ with SF level, from $3.3 \% / \mathrm{h}$ for LSF to $4.9 \% / \mathrm{h}$ for HSF calves. Ruminal fractional passage rate of $\mathrm{Cr}$, representing straw, increased $(P=$ 0.003 ) with SF level, from $1.3 \% / \mathrm{h}$ for LSF to $1.7 \% / \mathrm{h}$ for $\mathrm{HSF}$ calves. Ruminal passage rates of $\mathrm{C}_{36}$ and $\mathrm{Cr}$ were unaffected by $\mathrm{R}: \mathrm{C}$ ratio.

\section{DISCUSSION}

\section{Ruminal Drinking and Passage of MR}

Although the majority of MR is assumed to bypass the rumen by means of the esophageal groove reflex,

Table 5. Effects of level of solid feed (SF; low vs. high) and roughage-to-concentrate ratio (R:C; 20:80 vs. 50:50) on weights of gastrointestinal compartments, contents, and DM content in veal calves ${ }^{1}$

\begin{tabular}{|c|c|c|c|c|c|c|c|c|}
\hline Item & \multicolumn{2}{|c|}{ Low SF } & \multicolumn{2}{|c|}{ High SF } & SEM & \multicolumn{3}{|c|}{$P$-value } \\
\hline \multicolumn{9}{|l|}{ Rumen } \\
\hline Total VFA, $\mathrm{mmol} / \mathrm{L}$ & 125 & 127 & 161 & 124 & 9.3 & 0.08 & 0.06 & 0.04 \\
\hline Empty weight, $\mathrm{kg}$ & 5.1 & 4.6 & 5.4 & 6.0 & 1.00 & 0.10 & 0.92 & 0.23 \\
\hline Contents, $\mathrm{kg}$ & 16.9 & 15.7 & 23.4 & 22.9 & 2.04 & $<0.001$ & 0.56 & 0.81 \\
\hline Empty weight, $\mathrm{kg}$ & 1.8 & 2.4 & 2.0 & 2.1 & 0.16 & 0.84 & 0.01 & 0.03 \\
\hline Contents, $\mathrm{kg}$ & 1.5 & 2.6 & 2.5 & 1.2 & 0.47 & 0.46 & 0.76 & 0.001 \\
\hline DM content, $\mathrm{g} / \mathrm{kg}$ & 44 & 69 & 81 & 83 & 11.0 & $<0.001$ & 0.03 & 0.01 \\
\hline \multicolumn{9}{|l|}{ Small intestine } \\
\hline Empty weight, kg & 5.0 & 5.4 & 5.0 & 5.0 & 0.35 & 0.47 & 0.44 & 0.48 \\
\hline Contents, $\mathrm{kg}$ & 3.7 & 4.0 & 4.7 & 3.8 & 0.52 & 0.35 & 0.40 & 0.14 \\
\hline DM content, $\mathrm{g} / \mathrm{kg}$ & 66 & 65 & 61 & 74 & 7.7 & 0.74 & 0.29 & 0.19 \\
\hline
\end{tabular}

${ }^{1}$ Dietary treatments included low or high level of solid feed (SF). The SF included 1 of 2 roughage-to-concentrate ratios (R:C; 20:80 vs. 50:50 on DM basis) and was fed in addition to a milk replacer. 
Table 6. Effects of level of solid feed (SF; low vs. high) and roughage-to-concentrate ratio (R:C; 20:80 vs. 50:50) on estimated fractional ruminal passage rate $(\mathrm{Kp})$ for $\mathrm{C}_{36}$ (concentrate) and $\mathrm{Cr}-\mathrm{NDF}$ (straw) in veal calves ${ }^{1}$

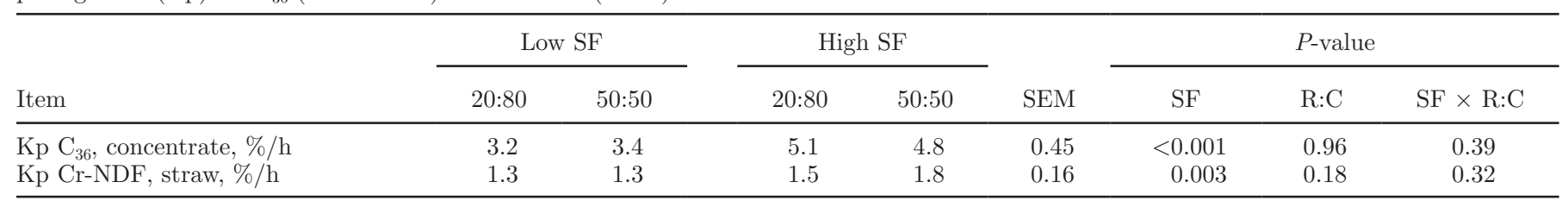

${ }^{1}$ Dietary treatments include low or high level of solid feed (SF). The SF included one of two roughage-to-concentrate ratios (R:C; 20:80 vs. 50:50 on DM basis) and was fed in addition to a milk replacer.

$* * P<0.01 ; * * P<0.001$

ruminal drinking is frequently observed in veal calves (Suárez et al., 2007; Berends et al., 2012b). In the current study, ruminal recovery of Co, supplied with the MR, averaged 20\%, which is similar to previous marker studies (Suárez et al., 2007; Berends et al., 2012b) but exceeds estimates from other marker studies $(<7 \%$; Labussière et al., 2014). Although SF level and R:C ratio did not affect ruminal Co recovery, the large variation in ruminal Co recovery complicates interpretation of the effect of SF level and R:C ratio on passage of MR through the remaining part of the digestive tract. To gain more insight in the gastrointestinal transit of MR, Co recovery in the abomasum, small intestine, and large intestine was expressed as a percentage of the oral dose corrected for rumen recovery (Figure 1), thereby neglecting passage of the marker from the rumen compartment within the 4-h period between administration and slaughter. These data showed that postrumen pas- sage kinetics of MR were hardly affected by SF intake or R:C ratio. In the current study, a large contrast in MR intake was observed between treatments, with LSF 50:50 calves receiving the largest amounts of MR and HSF 20:80 receiving the lowest amounts of MR. In ruminants, abomasal volume and the rate of digesta flow from the abomasum and along the small intestine are linearly related to the level of intake (Gregory et al., 1985). For MR, abomasal emptying rate is negatively related to meal volumes (Bell and Razig, 1973). Therefore, the reduction in abomasal recovery in HSF is likely related to the associated reduction in MR intake.

Total Co recovery averaged $84 \%$. The incomplete recovery indicates that CoEDTA may be partly absorbed. Although this marker has been used successfully to estimate passage kinetics (Huhtanen and Kukkonen, 1995), abomasal emptying rate (Holtenius et al., 2000), and ruminal drinking (Suárez et al., 2007; Berends et

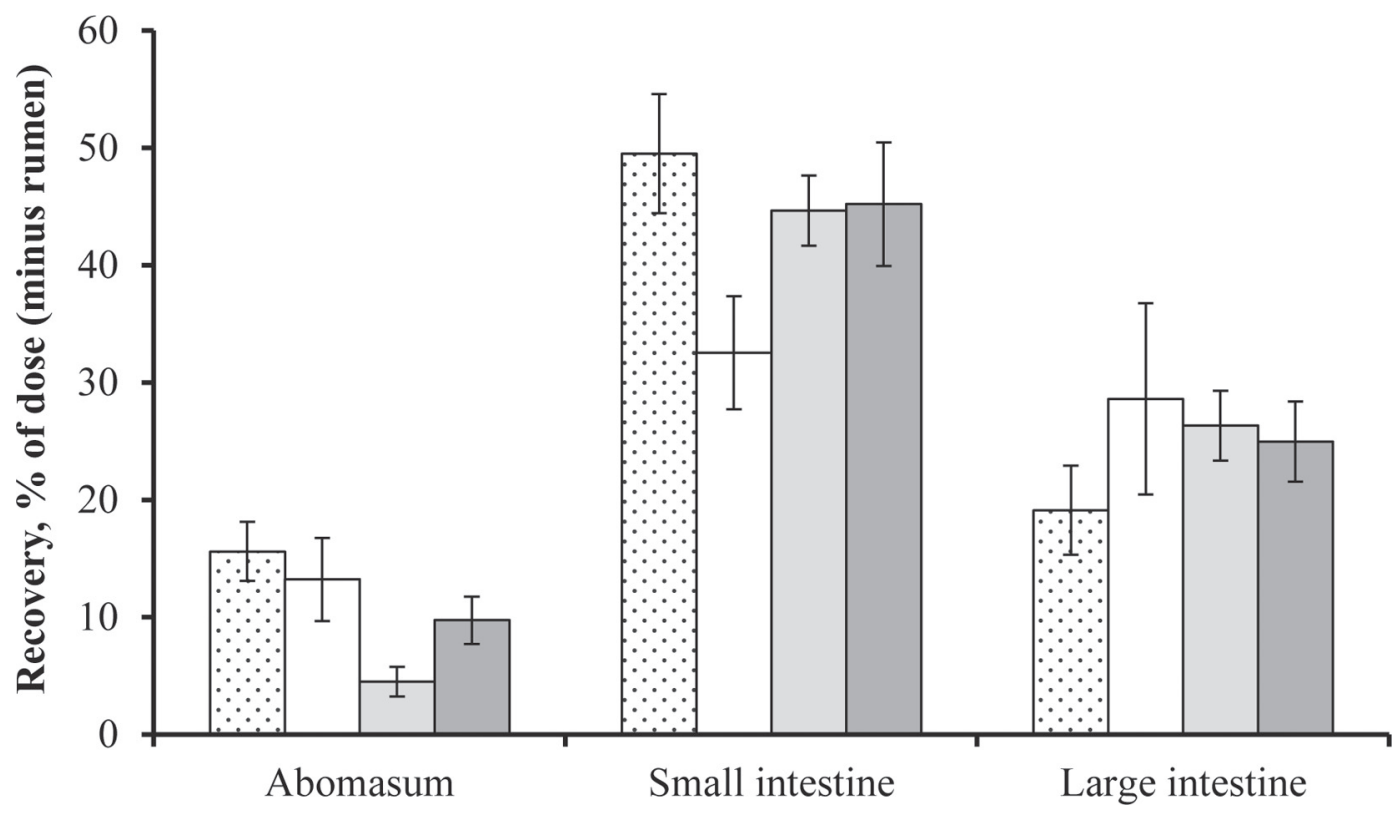

Figure 1. Cobalt recovery as a percentage (means $\pm \mathrm{SE}$ ) of the dose administered, corrected for rumen Co recovery. Abomasal Co recovery was affected by level of solid feed (SF; $P<0.01)$, but not by roughage-to-concentrate $(\mathrm{R}: \mathrm{C})$ ratio or the interaction. Recoveries in small and large intestine were unaffected by SF level, R:C ratio, or the interaction. The low SF 50:50 (R:C) treatment is represented by a dotted bar, low SF 20:80 by a white bar, high SF 50:50 by a light gray bar, and high SF 20:80 by a dark gray bar. 
al., 2012b), Co excretion via urine was found to be 2 to $3 \%$ in ruminants (Udén et al., 1980), suggesting that some amounts of Co could be absorbed from the digestive tract.

\section{Passage Rates of Concentrate and Straw}

From marker recovery data in the current study, we calculated fractional rumen passage rates assuming an exponential decay as commonly done in ruminant studies (e.g., Tamminga et al., 1989). Fractional passage rates of concentrates and straw were generally lower than previously reported for dairy calves around weaning (Hart and Polan, 1984; Lallès and Poncet, 1990; Vazquez-Anon et al., 1993) and adult ruminants fed only SF (Owens and Goetsch, 1986; Colucci et al., 1990). This could be due to the relatively low SF intake in our study, because calves obtained the vast majority of digestible energy from MR. Potentially, differences could be explained by a different particle size of the pulse-dosed straw compared with previously mentioned studies.

The observed increase in ruminal fractional passage rate with increasing $\mathrm{SF}$ intake and decreasing $\mathrm{MR}$ intake was previously observed in dairy calves (Broesder et al., 1990) and with increasing SF intake in adult ruminants (Owens and Goetsch, 1986; Robinson et al., 1987; Colucci et al., 1990). However, other studies found no effect of increasing SF intake on passage of particles in young ruminants (Hodgson, 1971a; Lallès and Poncet, 1990). The increase in SF intake also increased rumen contents in the current study, which is in accordance with the positive relationship observed between rumen fluid volume and SF intake in young calves during weaning (Hodgson, 1971b) and in dairy cows (Owens and Goetsch, 1986). A greater rumen volume enables a longer retention time and thus greater feed degradation, which may partly compensate for the increase in fractional passage rate.

Ruminal fractional passage rates of concentrate are typically greater than those of roughages, such as straw (Colucci et al., 1990), which can be explained by increased time for rumination and comminution to decrease particle size of roughages. The absence of an effect of $\mathrm{R}: \mathrm{C}$ ratio on passage rates of concentrate (Poore et al., 1990; Warner et al., 2013) and roughage (Poore et al., 1990; Rotger et al., 2005) has been demonstrated before, as reviewed by Offer and Dixon (2000) for cattle. A negative effect of concentrate proportion on rumen volume, as observed in adult ruminants (Owens and Goetsch, 1986), was absent in our study.

The relationship between $\mathrm{C}_{36}$ and $\mathrm{Cr}$ recovery in the different postrumen compartments was highly significant $(P<0.001)$ and strong $\left(\mathrm{R}^{2} \geq 0.80\right)$ for the tubular parts of the gut (Figure 2), but this was less clear for the abomasum $\left(R^{2}=0.49\right.$; Figure 2$)$ and the rumen $\left(\mathrm{R}^{2}=0.40\right.$; results not shown). These results suggest that rumen and abomasal emptying differ between concentrate and roughages, whereas passage through the remaining part of the gut is similar for concentrate and straw. This observation is similar to previous studies on passage behavior of solid and liquid markers through the postrumen sections of the gastrointestinal tract in dairy cows (Wylie et al., 2000; Pellikaan, 2004).

In conclusion, the low passage rates found for concentrate and straw in the current study can be explained by the low SF intake (or high MR intake). An increase in SF intake coincided with an increase in rumen volume. The ratio between $\mathrm{Cr}$ and $\mathrm{C}_{36}$ was similar in the small and large intestine, indicating that passage of concentrate and straw is mainly determined by rumen and abomasum emptying.

\section{Gastrointestinal Development}

Ruminal VFA concentrations observed in the current study were similar to VFA concentrations observed in growing calves and heifers provided with similar $\mathrm{R}: \mathrm{C}$ ratios (Vazquez-Anon et al., 1993; Rotger et al., 2005; Moody et al., 2007). The highest ruminal VFA concentrations were observed in calves fed a high level of $\mathrm{SF}$ with a 20:80 R:C ratio. This interaction $(P=$ 0.04 ) indicates greater rumen fermentation with large amounts of readily degradable fiber originating from concentrate. The increase in total VFA concentration was accompanied by a reduction in rumen $\mathrm{pH}$ in these calves. Abomasal weight increased with roughage inclusion, especially in LSF calves, but it remains unclear why this effect was less pronounced in HSF calves.

\section{CONCLUSIONS}

Ruminal drinking, as indicated from recovery of Co in the rumen, was not affected by SF intake and R:C ratio in veal calves. On average, $20 \%$ of the MR was recovered in the rumen. An increase in SF intake increased rumen passage rates of concentrates and straw as well as rumen volume. The differences in passage of concentrate and straw are mainly induced by variation in rumen and abomasum emptying, as indicated from the constant ratio between $\mathrm{Cr}$ (marker for straw) and $\mathrm{C}_{36}$ (marker for concentrate) in the small and large intestines. These data provide insight in passage kinetics of MR, roughage, and concentrate, and the interactions between $\mathrm{SF}$ intake and $\mathrm{R}: \mathrm{C}$ ratio. The current findings may be used for the development of mechanistic models simulating digestion of MR and SF and predicting growth in veal calves. 


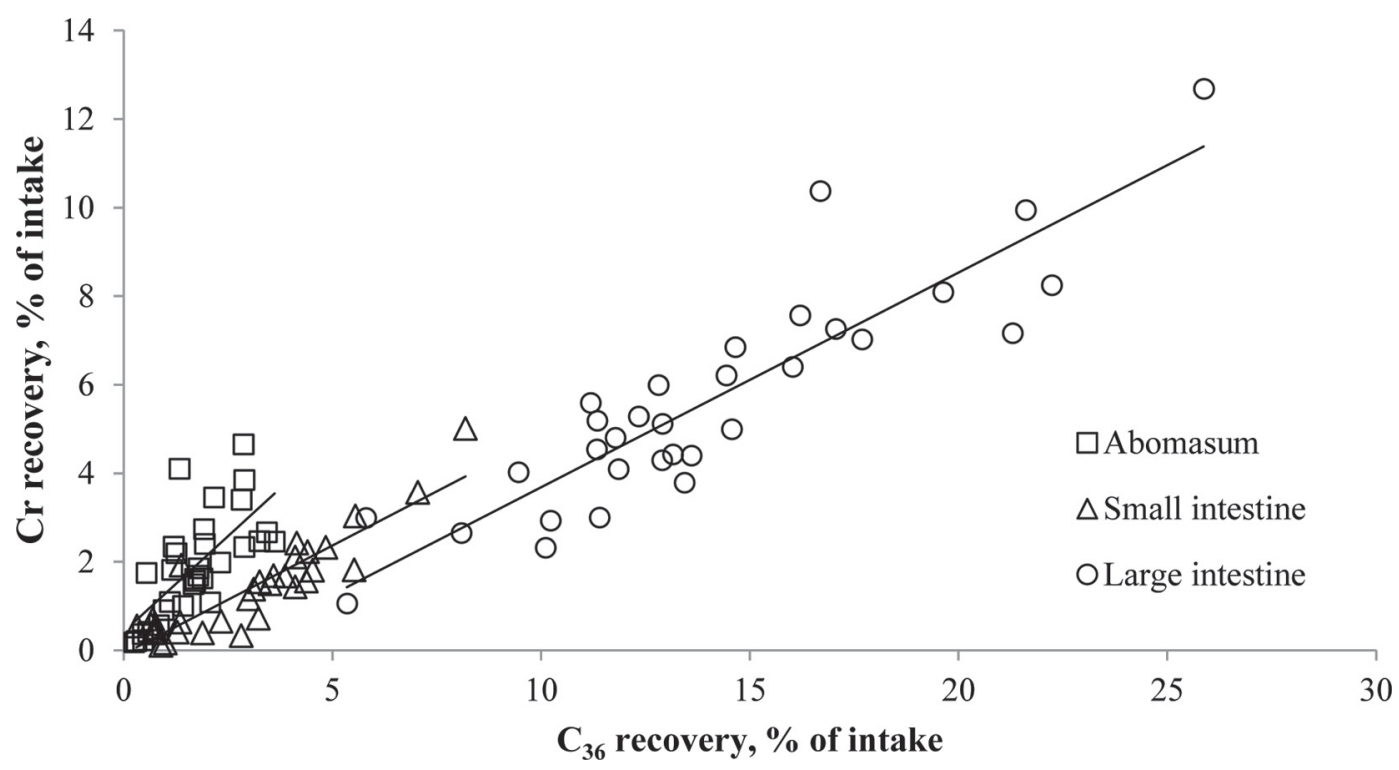

Figure 2. Relationship between hexatriacontane $\left(\mathrm{C}_{36}\right)$ recovery and chromium $(\mathrm{Cr})$ recovery in abomasum $\left(\square ; \mathrm{y}=0.86 \mathrm{x}+0.42 ; \mathrm{R}^{2}=0.49\right)$, small intestine $\left(\Delta ; \mathrm{y}=0.49 \mathrm{x}-0.08 ; \mathrm{R}^{2}=0.80\right)$, and large intestine $\left(\mathrm{O} ; \mathrm{y}=0.49 \mathrm{x}-1.17 ; \mathrm{R}^{2}=0.80\right)$. Cobalt was pulse-dosed as CoEDTA with milk replacer at $4 \mathrm{~h}$ before slaughter; $\mathrm{C}_{36}$ was pulse-dosed with concentrate at $24 \mathrm{~h}$ before slaughter; $\mathrm{Cr}$ was pulse-dosed as Cr-NDF with straw at $48 \mathrm{~h}$ before slaughter. Recoveries were determined in gastrointestinal compartments of veal calves. For each segment, the estimated regression coefficient was highly significant $(P<0.001)$.

\section{ACKNOWLEDGMENTS}

We thank Klaas Boeder, Bart Evers, Ewart van Voorst (VanDrie Group, Scherpenzeel, the Netherlands), Bert Beukers, André Jansen, Joswita van der Velde (Wageningen University, Wageningen, the Netherlands), Pieter Roskam, and Ralph Kok (Central Veterinary Institute, Lelystad, the Netherlands) for their skilled technical assistance. The Division for Earth and Life Sciences (ALW) of the Netherlands Organization for Scientific Research (NWO, The Hague, the Netherlands), and the Product Board Animal Feed (The Hague, the Netherlands) are gratefully acknowledged for financially supporting this research.

\section{REFERENCES}

Abe, M., T. Iriki, K. Kondoh, and H. Shibui. 1979. Effects of nipple or bucket feeding of milk-substitute on rumen by-pass and on rate of passage in calves. Br. J. Nutr. 41:175-181.

Bell, F. R., and S. Razig. 1973. Gastric emptying and secretion in the milk-fed calf. J. Physiol. 228:499-512.

Berends, H., J. J. G. C. van den Borne, S. J. J. Alferink, C. G. van Reenen, E. A. M. Bokkers, and W. J. J. Gerrits. 2012a. Low-protein solid feed improves the utilization of milk replacer for protein gain in veal calves. J. Dairy Sci. 95:6654-6664.

Berends, H., J. J. G. C. van den Borne, H. Mollenhorst, C. G. van Reenen, E. A. M. Bokkers, and W. J. J. Gerrits. 2014. Utilization of roughages and concentrates relative to that of milk replacer increases strongly with age in veal calves. J. Dairy Sci. 97:6475-6484.

Berends, H., C. G. van Reenen, N. Stockhofe-Zurwieden, and W. J. J. Gerrits. 2012b. Effects of early rumen development and solid feed composition on growth performance and abomasal health in veal calves. J. Dairy Sci. 95:3190-3199.

Bezabih, M., W. Pellikaan, A. Tolera, and W. Hendriks. 2011. Evaluation of n-alkanes and their carbon isotope enrichments $(\delta 13 \mathrm{C})$ as diet composition markers. Animal 5:57-66.

Broesder, J. T., M. B. Judkins, L. J. Krysl, S. A. Gunter, and R. K. Barton. 1990. Thirty or sixty percent milk replacer reduction for calves: Effects on alfalfa hay intake and digestibility, digestive kinetics and ruminal fermentation. J. Anim. Sci. 68:2974-2985.

Colucci, P., L. Chase, and P. Van Soest. 1982. Feed intake, apparent diet digestibility, and rate of particulate passage in dairy cattle. J. Dairy Sci. 65:1445-1456.

Colucci, P. E., G. Macleod, W. Grovum, I. McMillan, and D. Barney. 1990. Digesta kinetics in sheep and cattle fed diets with different forage to concentrate ratios at high and low intakes. J. Dairy Sci. 73:2143-2156.

Gregory, P. C., S. Miller, and A. Brewer. 1985. The relation between food intake and abomasal emptying and small intestinal transit time in sheep. Br. J. Nutr. 53:373-380.

Guilhermet, R., C. Mathieu, and R. Toullec. 1975. Transit des aliments liquides au niveau de la gouttiere oesophagienne chez le veau preruminant et ruminant. Ann. Zootech. 24:69-79.

Hart, S. P., and C. E. Polan. 1984. Effect of sodium bicarbonate and disodium phosphate on animal performance, ruminal metabolism, digestion, and rate of passage in ruminating calves. J. Dairy Sci. $67: 2356-2368$

Hodgson, J. 1971a. The development of solid food intake in calves. 4. The effect of the addition of material to the rumen, or its removal from the rumen, on voluntary food intake. Anim. Prod. 13:581-592.

Hodgson, J. 1971b. The development of solid food intake in calves. 2. Studies on the volume of rumen fluid, determined by an indirect method. Anim. Prod. 13:25-36.

Holtenius, K., K. Sternbauer, and P. Holtenius. 2000. The effect of the plasma glucose level on the abomasal function in dairy cows. J. Anim. Sci. 78:1930-1935.

Huhtanen, P., and U. Kukkonen. 1995. Comparison of methods, markers, sampling sites and models for estimating digesta passage ki- 
netics in cattle fed at two levels of intake. Anim. Feed Sci. Technol. 52:141-158.

ISO. 1997. Animal feeding stuffs - Determination of nitrogen content and calculation of crude protein content. ISO 5983. International Organization for Standardization, Geneva, Switzerland.

ISO. 1998. Animal feeding stuffs-Determination of moisture and other volatile matter content. ISO 6496. International Organization for Standardization, Geneva, Switzerland.

ISO. 1999. Animal feeding stuffs - Determination of fat content. ISO 6492. International Organization for Standardization, Geneva, Switzerland.

Kooijman, J., H. K. Wierenga, and P. R. Wiepkema. 1991. Development of abnormal oral behaviour in group-housed veal calves: Effects of roughage supply. Pages 54-58 in Proc. Int. Symp. New Trends Veal Calf Prod. Wageningen UR, Wageningen, the Netherlands.

Labussière, E., H. Berends, M. S. Gilbert, J. J. G. C. van den Borne, and W. J. J. Gerrits. 2014. Estimation of milk leakage into the rumen of milk-fed calves through an indirect and repeatable method. Animal 8:1643-1652.

Lallès, J. P., and C. Poncet. 1990. Rate of passage of digesta during and after weaning in calves fed concentrate diets containing pea or soya-bean meal. Livest. Prod. Sci. 24:333-345.

Mayes, R. W., C. S. Lamb, and P. M. Colgrove. 1986. The use of dosed and herbage n-alkanes as markers for the determination of herbage intake. J. Agric. Sci. 107:161-170.

Moody, M. L., G. Zanton, J. Daubert, and A. Heinrichs. 2007. Nutrient utilization of differing forage-to-concentrate ratios by growing Holstein heifers. J. Dairy Sci. 90:5580-5586.

Offer, N., and J. Dixon. 2000. Factors affecting outflow rate from the reticulo-rumen. Pages 833-844 in Proc. Nutrition Abstracts and Reviews. Series B, Livestock Feeds and Feeding. CAB International, Wallingford, Oxfordshire, UK.

Owens, F., and A. Goetsch. 1986. Digesta passage and microbial protein synthesis. Pages 196-223 in Control of Digestion and Metabolism in Ruminants. L. Milligan, W. Grovum, and A. Dobson, ed. Prentice-Hall, Englewood Cliffs, NJ.

Pellikaan, W. 2004. Passage of 13C-labelled feed components through the digestive tract of dairy cows. Pages 119-144 in Wageningen Institute of Animal Sciences, Animal Nutrition Group. PhD thesis. Wageningen University, Wageningen, the Netherlands.

Pellikaan, W. F., E. Stringano, J. Leenaars, D. J. G. M. Bongers, S. van Laar-van Schuppen, J. Plant, and I. Mueller-Harvey. 2011. Evaluating effects of tannins on extent and rate of in vitro gas and $\mathrm{CH}_{4}$ production using an automated pressure evaluation system (APES). Anim. Feed Sci. Technol. 166-167:377-390.

Pellikaan, W. F., M. W. A. Verstegen, S. Tamminga, J. Dijkstra, and W. H. Hendriks. 2013. $\delta 13 \mathrm{C}$ as a marker to study digesta passage kinetics in ruminants: A combined in vivo and in vitro study. Animal 7:754-767.
Poore, M. H., J. Moore, and R. Swingle. 1990. Differential passage rates and digestion of neutral detergent fiber from grain and forages in 30,60 and 90\% concentrate diets fed to steers. J. Anim. Sci. 68:2965-2973.

Rijnen, M. M., M. Verstegen, M. Heetkamp, J. Haaksma, and J. Schrama. 2001. Effects of dietary fermentable carbohydrates on energy metabolism in group-housed sows. J. Anim. Sci. 79:148-154.

Robinson, P. H., S. Tamminga, and A. M. van Vuuren. 1987. Influence of declining level of feed intake and varying the proportion of starch in the concentrate on rumen ingesta quantity, composition and kinetics of ingesta turnover in dairy cows. Livest. Prod. Sci. $17: 37-62$.

Rotger, A., A. Ferret, S. Calsamiglia, and X. Manteca. 2005. Changes in ruminal fermentation and protein degradation in growing Holstein heifers from 80 to $250 \mathrm{~kg}$ fed high-concentrate diets with different forage-to-concentrate ratios. J. Anim. Sci. 83:1616-1624.

Salt, C. A., R. W. Mayes, and D. A. Elston. 1992. Effects of season, grazing intensity and diet composition on the radiocaesium intake by sheep on re-seeded hill pasture. J. Appl. Ecol. 29:378-387.

Suárez, B. J., C. G. Van Reenen, N. Stockhofe, J. Dijkstra, and W. J. J. Gerrits. 2007. Effect of roughage source and roughage to concentrate ratio on animal performance and rumen development in veal calves. J. Dairy Sci. 90:2390-2403.

Tamminga, S., P. H. Robinson, M. Vogt, and H. Boer. 1989. Rumen ingesta kinetics of cell wall components in dairy cows. Anim. Feed Sci. Technol. 25:89-98.

Udén, P., P. E. Colucci, and P. J. Van Soest. 1980. Investigation of chromium, cerium and cobalt as markers in digesta. Rate of passage studies. J. Sci. Food Agric. 31:625-632.

Van Soest, P. J., J. Robertson, and B. Lewis. 1991. Methods for dietary fiber, neutral detergent fiber, and nonstarch polysaccharides in relation to animal nutrition. J. Dairy Sci. 74:3583-3597.

Vazquez-Anon, M., A. Heinrichs, J. Aldrich, and G. Varga. 1993. Postweaning age effects on rumen fermentation end-products and digesta kinetics in calves weaned at 5 weeks of age. J. Dairy Sci. $76: 2742-2748$.

Veissier, I., A. R. Ramirez De La Fe, and P. Pradel. 1998. Nonnutritive oral activities and stress responses of veal calves in relation to feeding and housing conditions. Appl. Anim. Behav. Sci. 57:35-49.

Warner, D., J. Dijkstra, S. Tamminga, and W. Pellikaan. 2013. Passage kinetics of concentrates in dairy cows measured with carbon stable isotopes. Animal 7:1935-1943.

Webb, L. E., E. A. Bokkers, B. Engel, W. J. Gerrits, H. Berends, and C. G. van Reenen. 2012. Behaviour and welfare of veal calves fed different amounts of solid feed supplemented to a milk replacer ration adjusted for similar growth. Appl. Anim. Behav. Sci. 136:108-116.

Wylie, M. J., W. Ellis, J. Matis, E. Bailey, W. James, and D. Beever. 2000. The flow of forage particles and solutes through segments of the digestive tracts of cattle. Br. J. Nutr. 83:295-306. 